\title{
THE POTENTIAL OF BLACK GLUTEN AND RED RICE IN RATIONS ON THE BIOLOGICAL VALUES AND IDEALLY BODY SCORE OF HEALTHY "MINI REX RABBIT"
}

\author{
Romziah Sidik
}

\section{Abstract}

The potentially of black gluten and red rice in rations was observed on performed of biological values and body condition score of Mini Rex Rabbits. Twelve male Mini Rex Rabbits averaging 2 months of age, body weight $1.95 \mathrm{~kg}$ were used as experimental animals. Four variations of ration: $P_{0}$ a commercial, $P_{1}, P_{2}$, and $P_{3}$ contains white, red, and black gluten rice, respectively. Research pattern of Complete Randomized

Corresponding Author: Romziah Sidik

Received: 03 October 2017 Accepted: 10 October 2017 Published: 29 November 2017

Publishing services provided by Knowledge

(c) Romziah Sidik. This article is distributed under the terms of the Creative Commons Attribution License, which permits unrestricted use and redistribution provided that the original author and source are credited.

Selection and Peer-review under the responsibility of the VMIC Conference Committee.
Design include four group animals with three replications. The animals were treated by different ration as well as their treatment group during 8 weeks trials, and each animal received Alfalfa hay $10 \mathrm{~g} / \mathrm{h} / \mathrm{d}$ as a basic nutrient. Fecal and urine were collected every day along feeding trials and it's analyzed by proximate analysis. Body weight and body condition score measured once a week.

Results, crude protein content 19.0\%, 21.74\%, 22.5\% and $23.1 \%$ in commercial ration, rations contains white, red and black gluten rice, respectively. Body weight, live weight gain, and feed intake were not significantly differences ( $P>0.05)$ among treatment group. The ideal body condition score $(P<0.05) 3.07$ to 3,17 were obtained in Mini Rex Rabbit received ration contains white, red and black gluten rice, and it was positive correlation $(r=0.72)$ with body weight. Feed conversion 21.13 was higher $(P<0.05)$ in Rabbit received white rice ration then other groups only 6.69 to 12.72 . Nitrogen balance 1.97 was higher $(P<0.05)$ in Rabbit received black gluten rice ration. It concluded, black gluten rice is potential for ideal body condition score and healthy Mini Rex Rabbit.

\section{INTRODUCTION}

The Rex rabbits originally came from France then developed in the United States. Originally the short fur varies in color from fur, white, light brown, satin, bluish, black with red and blue eyes. Nowadays with the improvement of genetic quality, the condition of the fur is smoother, long, soft which is the result of mutagenic. The body size varies 
from 5-7 kg to large, some medium type about 3-4 kg and also a type of light called mini rex type that the size $1.5 \mathrm{~kg}$ only. Rabbit hair is called "fur", a good growth of feathers is characterized by the rapid growth of fur, and size of the fur is long, soft and smooth and shiny and not easily fall out. The rate of body and feather growth and physiological processes of the body is influenced by the quantity and quality of feed. Balance of protein, energy, vitamins and minerals, greatly the amount of feed consumption, the value of feed conversion, the balance of nitrogen, the digestibility value of organic mattern [6], and the use of metabolic energy. Black rice is a common food ingredients as a functional nutritious food raw material to prevent metabolic diseases, because it contains low calorie than white rice, is useful to prevent diabetes mellitus, heart disease, prevent obesity, anti-inflammatory and contain anthocyanins that is purple, bluish, blackish, is a flavonoid compound such as grape and black currant as an antioxidant [2]; Iron content in black glutinous function in the synthesis of hemoglobin, myoglobin in the bone marrow, liver and muscle tissue. The other side of red rice also contains anthocyanins that act as antioxidants [3], in addition to containing vitamin B and several mineral elements such as selenium, calcium, zinc, manganese, magnesium which has anti: cancer, osteoporosis, heart attack, bone and teeth defense, and inflammatory. Rabbits include animals that are very sensitive to environmental conditions, easily startled, and nervous. Therefore it is necessary to formulate a safe feeding formula for the health of rabbits, longevity, especially for rabbits, do not need to be too fat (obey), but ideal posture body and avoid heart attack and diabetes mellitus. To meet ideally body condition score of Mini Rex Rabbit, it's better to compose the nutritious ration which are containing black gluten and red rice in diet. For measuring the effectiveness of the formulation rations, it should be measured the biological values of these formulas, such as Nitrogen balance and Body Condition Score. Nitrogen balance it means the differences between nitrogen in put by the animal from the feed and nitrogen produced by the animal, like fecal and urine nitrogen excreted by the animals. There are positive nitrogen balance, if the nitrogen input by the animal is higher than nitrogen output in the feces and urine. This condition shows that animal in normal and healthy condition. However, if the negative nitrogen balance, it means the total nitrogen input by the animal is lower than nitrogen output in fecal and urine, so it indicate that animal is unhealthy, something happened with the metabolic process in digestive system [4].

The purpose of this study is to prove the potential of black gluten and red rice as the ingredients of making concentrate feed for Mini Rex Rabbit, and its effects on normally digestion process in digestive tract, prevention of obesity and bring the ideally body condition score. The benefits of this research are: finding the right formula with black 
glutinous and red rice to feed the rabbit with has high palatability, nutritious and gives good results on animal health, ideal hair and body growth as pet animal. The results of this study will provide a positive impact on feed safety in the development of healthy and safe rabbits for the keepers and owners, thus providing psychological effects to rabbit lovers.

\section{RESEARCH METHOD}

Twelve male rabbits Mini Rex two-month-old with an average weight of about 1.8 $\mathrm{kg}$ divided into four treatment groups ( $\mathrm{P}_{0}, \mathrm{P}_{1}, \mathrm{P}_{2}$ and $\mathrm{P}_{3}$ ). Four variations of feed to be tested in this study include: Po consisting of commercial concentrate feed and Alfalfa hay; $\mathrm{P}_{1}$ concentrate feed contains white rice and Alfalfa hay; $\mathrm{P}_{2}$ feed of red rice concentrate and Alfalfa hay; $P_{3}$ feed black glutinous rice concentrate and Alfalfa hay. The experimental design designed for this study was: Completely Randomized Design ( $4 \times 3$ replicates). Tests on the quality and effect of feed on the performance of Rabbit Mini Rex is executed for 8 weeks with a period of adaptation for one week. Drinking water is provided with sufficient quantity or ad libitum by using a nipple drinker system to be hygienic. Measurement of feed intake was done on a daily basis, and weighing was done once a week during the experiment. Weight collection and weighing of stool and urine were carried out every day of the week before the study ended. Parameters measured include: body weight, body condition score (body condition score / BCS) consumption, nitrogen balance, protein and digestibility efficiency, digestibility and efficiency of organic matter use. Each type of feed, as well as feces of guinea pigs were analyzed by proximate using the Wendy's System. While the urine only analyzed my nitrogen content to measure the parameters of Balance - Nitrogen. The data obtained were analyzed in accordance with the analysis method of Variance (ANOVA) using SPSS software version 13.00 .

\section{RESULTS}

Table 1, showed the chemical composition of Alfalfa hay, commercial feed, concentrate feed containing black gluten rice, white rice, and red rice. The dry matter content of alfalfa hay $88,3 \%$, in commercial and the other concentrate feeds around 94.5 to $95.9 \%$. However, the protein content in Alfalfa hay quite high, it is $24.6 \%$, in commercial feed $19.0 \%$, the other concentrate feeds was $22.5,21.7$, and $23.1 \%$ of protein content, respectively. The fat content $7.1 \%$ in concentrate contain white rice and the 
TABle 1: The Chemical Composition of Alfalfa hay, Commercial Rabbit Feed, Concentrate Feed Containing Black Gluten, White and Red Rice.

\begin{tabular}{|c|c|c|c|c|c|c|}
\hline Type of Feed & $\begin{array}{c}\text { Dry } \\
\text { Matter, \% }\end{array}$ & Ash, $\%$ & $\begin{array}{c}\text { Crude } \\
\text { Protein,\% }\end{array}$ & Fat, $\%$ & $\begin{array}{l}\text { Crude } \\
\text { Fiber, } \%\end{array}$ & $\begin{array}{l}\text { Nitrogen } \\
\text { Free } \\
\text { Extract, \% }\end{array}$ \\
\hline Alfalfa hay & 88.3 & 13.9 & 24.8 & 1.9 & 19.7 & 28.0 \\
\hline Commercial feed & 94.5 & 9.4 & 19.0 & 9.3 & 19.7 & 36.9 \\
\hline $\begin{array}{l}\text { Black Gluten Rice } \\
\text { Concentrate feed }\end{array}$ & 94.5 & 19.2 & 22.52 & 10.0 & 10.4 & 32.4 \\
\hline $\begin{array}{l}\text { White Rice Con- } \\
\text { centrate feed }\end{array}$ & 95.6 & 18.0 & 21.7 & 7.1 & 11.6 & 37.0 \\
\hline $\begin{array}{l}\text { Red Rice Concen- } \\
\text { trate feed }\end{array}$ & 95.5 & 16.0 & 23.1 .0 & 9.6 & 10.2 & 36.9 \\
\hline
\end{tabular}

other concentrates range about 9.3 to $10 \%$. The fiber matter in commercial feed was $19.4 \%, 10.2$ to $11.6 \%$ in three other concentrate feeds. Nitrogen free extract range about 32.4 to $37.0 \%$. Ash content in commercial feed was $9.4 \%$, it is lower compared to the other concentrate feeds which were range about 16.0 to $19.2 \%$, while ash content in Alfalfa hay was $13.9 \%$.

The average initial body weight of Mini Rex Rabbit $1.95 \mathrm{~kg}$ in all group treatments, than it were increased to be 2.05 to $2.27 \mathrm{~kg}$ after treated by differences rations, however, the final body weight were not significant ( $P>0.05)$ among group treatment. However, the Body Condition Score (BCS) were significantly different $(\mathrm{P}<0.05)$, and the higher $\mathrm{BCS}((\mathrm{P}<0.05)$ was found in group received commercial ration about 3.55, and no significant $(P>0.05)$ differences of BCS among Mini Rex Rabbit received ration contains white, red, and black gluten rice, there were 3.17 in group received ration contain white rice, 3.08 in both groups received red and or black gluten rice. The feed intake range about 62.51 to $70.29 \mathrm{~g} / \mathrm{h} / \mathrm{d}$, and there were no significant ( $P>0.05$ ) different among treatments group. Feed conversion was higher $(P<0.05)$ in the group received ration contain white rice, it about 21.11, compared to other groups range about 6.69 to 12.72 . These data were performed in Table 1. Figure 1, showed the position of final body weight and Body condition Score of all treatments group.

Nitrogen input from feed was higher $(\mathrm{P}<0.05)$ in group Mini Rex Rabbit received black gluten rice, it was $2.51 \mathrm{~g} / \mathrm{h} / \mathrm{d}$. The Nitrogen input from the other group about 1.90 to $2.45 \mathrm{~g} / \mathrm{h} / \mathrm{d}$, and there were no significantly ( $P>0.05$ ) different. Nitrogen output from fecal and urine were not significantly $(P>0.05)$ different among groups Rabbit received commercial ration, white rice ration, red rice and black gluten rice rations, The output Nitrogen in fecal around 0.48 to $0.61 \mathrm{~g} / \mathrm{h} / \mathrm{d}$, and output Nitrogen from urine ranged 
TABle 2: Mean Initial and Final Body Weight, Live Weight Gain, Body Condition Score, Feed Intake and Feed Conversion of Mini Rex Rabbit Based on Different Ration.

\begin{tabular}{|c|c|c|c|c|}
\hline \multirow[t]{2}{*}{ Parameter } & \multicolumn{4}{|c|}{ Rations } \\
\hline & $\begin{array}{c}\text { Po } \\
\text { Commercial }\end{array}$ & $\begin{array}{l}\text { P1 Contains } \\
\text { White Rice }\end{array}$ & $\begin{array}{l}\text { P2 Contains } \\
\text { Red Rice }\end{array}$ & $\begin{array}{c}\text { P3 Contains } \\
\text { Black Gluten } \\
\text { Rice }\end{array}$ \\
\hline Initial body weight, kg. & 1.93 & 1.97 & 1.95 & 1.93 \\
\hline Final body weight, kg. & 2.27 & 2.07 & 2.12 & 2.05 \\
\hline Live weight gain, g/h/d. & 6.7 & 3.57 & 4.52 & 3.25 \\
\hline Body Condition Score /BCS. & $3.55^{a}$ & $3.17^{b}$ & $3.08^{b}$ & $3.08^{b}$ \\
\hline Dry Matter Feed Intake, g/h/d. & 62.51 & 70.29 & 68.50 & 69.73 \\
\hline Feed Conversion & $6.69^{b}$ & $21.13^{a}$ & $11.37^{b}$ & $12.72^{b}$ \\
\hline
\end{tabular}

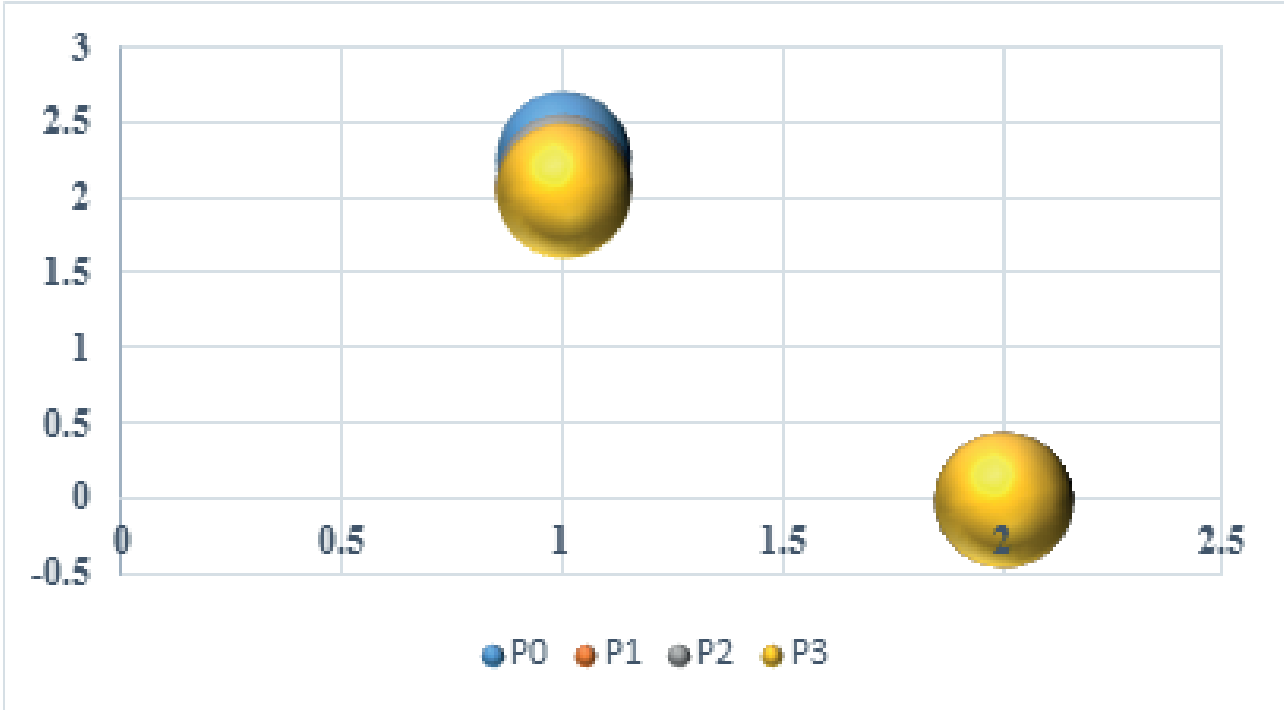

Figure 1: Body Weight and Body Condition Score of Mini Rex Rabbit Based on Difference Ration.

about 0.38 to $0.57 \mathrm{~g} / \mathrm{h} / \mathrm{d}$. Therefore, any significant differences $(P<0.05)$ of Nitrogen Balance among treatments group, and the higher $(\mathrm{P}<0.05)$ of Nitrogen Balance was in group Mini Rex Rabbit received ration contain black gluten rice, it was 1.97. The range of Nitrogen Balance from the other groups ranged about 1.27 to 1.93, and there were no significantly $(P>0.05)$ differences among these three group treatments. These data were performed in Table 3. 
TABLE 3: Mean of Nitrogen Input, Nitrogen Output in Fecal and Urine by Mini Rex Rabbit Based on Different Ration.

\begin{tabular}{l|c|c|c|c|}
\hline & \multicolumn{5}{|c}{ Rations } \\
\hline & $\begin{array}{c}\text { Po } \\
\text { Commercial }\end{array}$ & $\begin{array}{c}\text { P1 Contains } \\
\text { White Rice }\end{array}$ & $\begin{array}{c}\text { P2 Contains } \\
\text { Red Rice }\end{array}$ & $\begin{array}{c}\text { P3 Contains } \\
\text { Black Gluten } \\
\text { Rice }\end{array}$ \\
\hline Nitrogen input from feed, g/h/d. & $1.90^{b}$ & $2.45^{a}$ & $2.43^{a}$ & $2.51^{a}$ \\
\hline Nitrogen output in fecal, g/h/d. & 0.57 & 0.48 & 0.61 & 0.49 \\
\hline Nitrogen output in urine, g/h/d. & 0.57 & 0.38 & 0.42 & 0.48 \\
\hline Nitrogen Balance & $1.27^{b}$ & $1.93^{a}$ & $1.77^{a}$ & $1.97^{a}$ \\
\hline$a, b$ Superscript at the same row were significantly $(\mathrm{P}<0.05)$ difference. &
\end{tabular}

\section{Discussion}

In the researchlive weight gain of Mini Rex Rabbits were not affected by the diet which is commercial feed and or concentrate contain black gluten rice, white and or red rice. Nutrient requirement for growing rabbit include $16 \%$ protein, $2 \%$ crude fat, crude fiber around $10-12 \%$ [4]. Based on the nutrient composition of the diets used in the research, almost its nutrients slightly higher compare to the standard of nutrient requirement by rabbits. These diets were influenced to the Body Condition Score of Mini Rabbits, and it were higher when Mini Rex Rabbits received commercial feed, and or concentrate contain white and or red rice. However, when Mini Rex Rabbit fed concentrate feed contain black gluten rice showed on ideally Body Condition Score, it was 3.o. The ideal Body Condition Score of rabbits have specific body shape with smooth curve from neck to tail, and from hip to hip; Spine, rib and hip bone were not sharp prominent, but it were easily to fill or touching, also it look like covered by thick beautiful fur whit shiny and stronger, it's not easy to fall out of fur. If the score of BCS of rabbit is 1 , it means to thin, and score 2 also thin, but if the score of BCS of rabbit is 4 , it shows overweight, and score 5 show obesity [1]. Although the Dry Matter Intake (DMI) were not significant different among treatment group, the feed conversion (FC) of Mini Rex Rabbits were affected by the type of diet. Concentrate contain white rice was affected on increasing the feed conversion values of Mini Rex Rabbit, and the feed efficiency was lower compared to other treatments groups, such as commercial feed, concentrate contain black gluten rice and or red rice were more efficiently.

The Nitrogen input from concentrate feed contain black gluten rice, white and or red rice were higher compared to commercial feed for rabbits. It followed by higher on Nitrogen Balance of Mini Rex Rabbits when consumed concentrate feed contain black 
gluten rice, than followed by Mini Rex Rabbit fed commercial feed, and or concentrate contain white and or red rice were given on positive nitrogen balance too. Black Gluten and red rice were contain high on vitamin B, low energy, increasing protein in the feed ration, contain some flavonoid agent as anthocyanins were performed as antioxidant, anti-obesity, and its supported the healthy rabbit to have longevity of their live [7].

\section{Conclusion}

Black Gluten Rice and red rice were potential as feed ingredient for Mini Rex Rabbit diet with the beneficial effects on the increasing protein content in ration, performed the ideal Body Condition Score, the lower feed conversion, high on Nitrogen input and Positive Balance Nitrogen in Mini Rex Rabbit.

\section{Authors Statement}

No conflict interest in the research.

\section{Acknowledgment}

The research team would like to say thank you to the Dean of Faculty of Veterinary Medicine, Airlangga University for supporting the Research Grand and Publications.

\section{References}

[1] De la Fuente, L.F. and Rosell, and J.M. 2015. Body weight and body condition of breeding rabbits in commercial units. JAS Vol. 90 No. 9, p. 3252-3258.

[2] Duyi S., Amit, B.D., Deka, S.C. 2017. Pigmented rice a potential source of bioactive compounds: a review. International Journal of Food. Wiley Online Library

[3] Kushwaha, U.K.S. 2016. Black Rice: Research, History and Development. https:// books . google. com/books? isbn=3319301535

[4] Halls, A.E. 2010. Nutritional Requirement for Rabbits. Nutreco Canada. www.nutrecocanada.com

[5] Siddaramanna, B.S.V., Reddy H.S., Madhusudhan, B.H., Manjunatha, P, Mohan, K., Jayashankar, 2009. Effect of Drier Brewer's Grains as a Source of Fiber in the Diet of Anggora Rabbits on the Growth Performance. Pakistan Journal of Nutrition 8 (8): 1167-1169. 
[6] Thierry, G. and Rachel, B. Use of digestible fiber in replacement to available carbohydrates: Effect on digestion, rate of passage and caecal fermentation pattern during the growth of the rabbit. https://doi.org/10.1016/S0301-6226(99)001232Wen

[7] Wen, H.L, Qi Xuan C., Jing M., and Tong W. 2011. Red and Black Rice Decrease Atherosclerotic Plaque Formation and Increase Antioxidant Status in Rabbits. The American Society for Nutritional Sciences. 